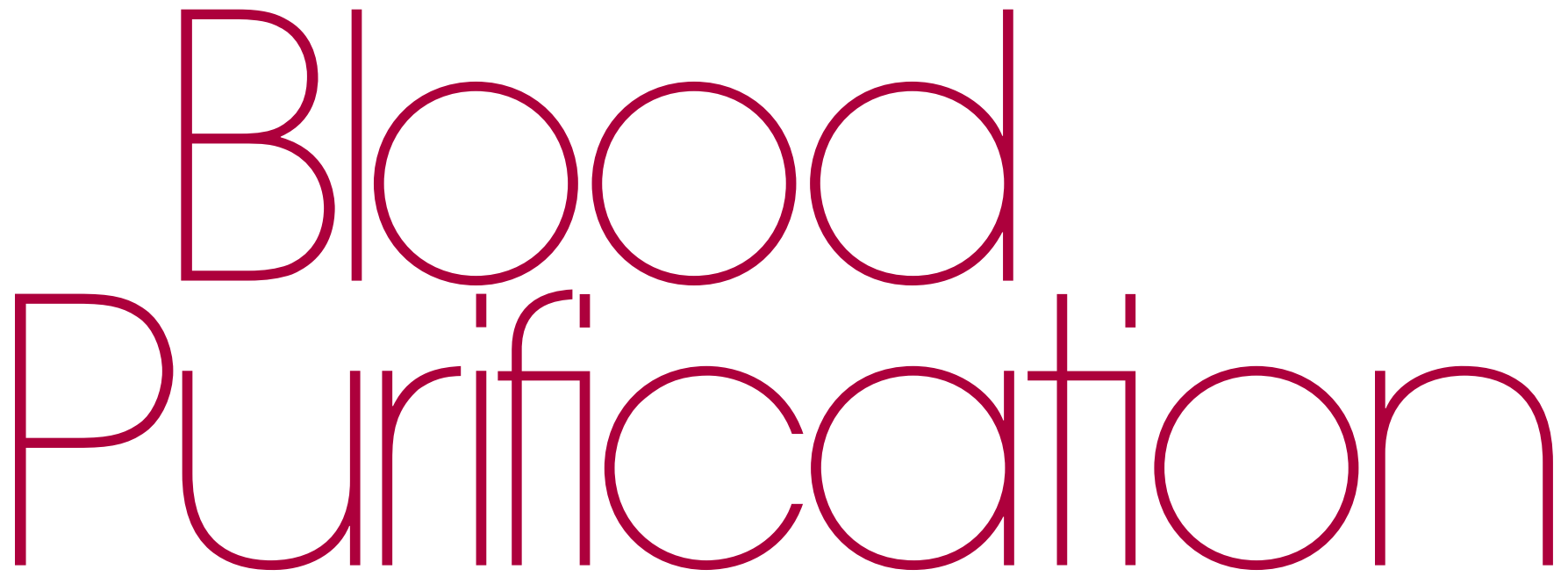

International Society
of Blood Purification (ISBP)

III Japanese Society for

If Hemodiafiltration (JS-HDF)

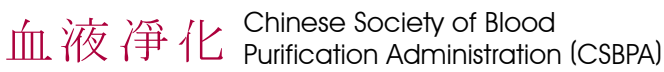




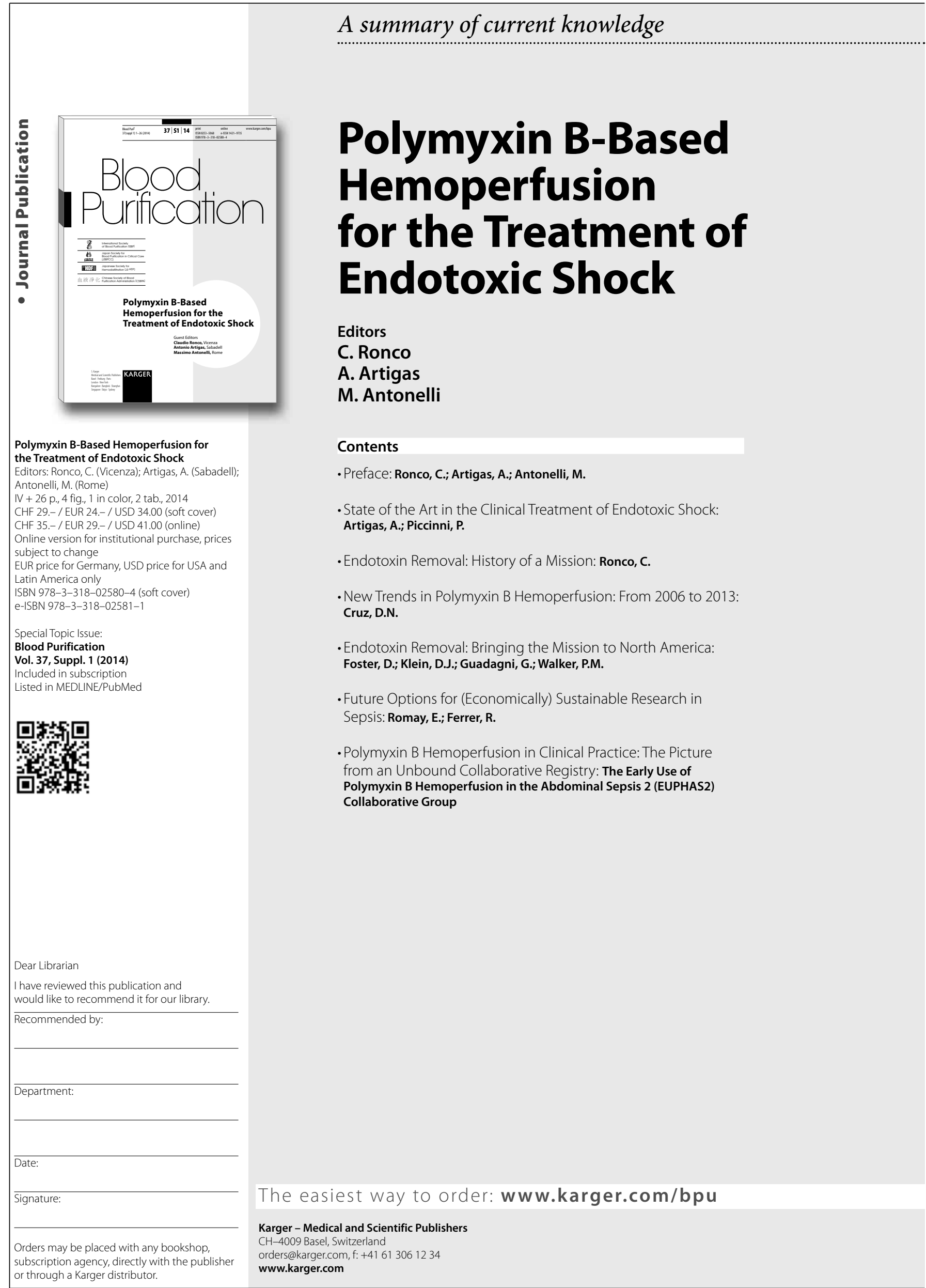


International Society of Blood Purification Editorial Representative

G. Lonnemann, Hannover

\section{JSBPCC}

Japan Society for Blood Purification in Critical Care Editorial Representatives

S. Oda, Chiba

K. Matsuda, Yamanashi

\section{国形目}

Japanese Society of Hemodiafiltration Editorial Representative

A. Yamashita, Tokyo

血液凈化

Chinese Society of Blood Purification Administration Editorial Representative

M. Wang, Beijing
Official Journal of the International Society of Blood Purification (ISBP) Official Journal of the Japan Society for Blood Purification in Critical Care (JSBPCC) Official Journal of the Japanese Society of Hemodiafiltration (JS-HDF) Official Journal of the Chinese Society of Blood Purification Administration (CSBPA)

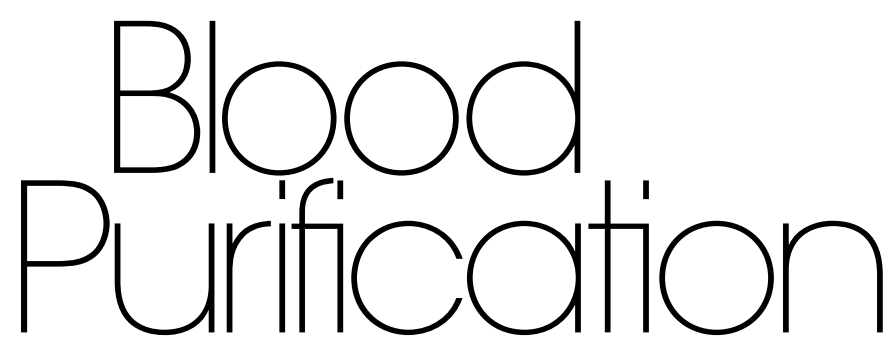

Founded 1983 by K. Schaefer; continued by L.W. Henderson (1989-2000), K.M.L. Leunissen (2001-2007)

\section{Editor-in-Chief}

C. Ronco, Vicenza

\section{Critical Care Nephrology}

Stefan D. Anker, Berlin Massimo Antonelli, Rome Sean M. Bagshaw, Edmonton, Alta. Ian C. Baldwin, Heidelberg, Vic. Fabio Barbarigo, Vicenza Rinaldo Bellomo, Melbourne, Vic. Guido Bertolini, Ranica W. Kline Bolton, Charlottesville, Va. Joseph V. Bonventre, Boston, Mass. John Burkart, Winston-Salem, N.C. Jorge Cerda, Albany, N.Y. Lakhmir Chawla, Washington, D.C. Maria Rosa Costanzo, Naperville, Ill. Dinna N. Cruz, Vicenza Andrew Davenport, London Salvatore Di Somma, Rome Enrico Fiaccadori, Parma Mihai Gheorghiade, Chicago, Ill. Stuart L. Goldstein, Cincinnatti, Ohio Michael Haase, Magdeburg

William L. Henrich, San Antonio, Tex. Patrick Honoré, Brussels

Eric Hoste, Ghent

Nevin Katz, Washington, D.C.

\section{Peritoneal Dialysis}

Richard Amerling, New York, N.Y. George L. Bakris, Chicago, Ill. Jordi Bover, Barcelona Joanne M. Bargman, Toronto, Ont. Edwina A. Brown, London Giovambattista Capasso, Naples Ricardo Correa-Rotter, Mexico Carlo Crepaldi, Vicenza Olivier Devuyst, Zurich Mariano Feriani, Mestre Fredric Finkelstein, New Haven, Conn. Guido Garosi, Siena David Goldsmith, London Roger N. Greenwood, Stevenage Olof Heimburger, Stockholm Achim Joerres, Berlin Raymond Krediet, Amsterdam Zhi-Hong Liu, Nanjing Francesca Martino, Vicenza Rajnish Mehrotra, Seattle, Wash. Piergiorgio Messa, Milan Andrew Mooney, Leeds K. Shivanand Nayak, Hyderabad Karl D. Nolph, Columbia, Mo.

\section{Hemodialysis}

Pedro Aljama, Cordoba

Stefano Bianchi, Arezzo

Prem K.G. Chandran, Des Moines, Iowa John Collins, Auckland Rosanna Coppo, Turin Adrian A. Covic, Iasi Mario Cozzolino, Milan Angel M. de Francisco, Santander Francesco Galli, Perugia Victor Gura, Beverly Hills, Calif. Stephan von Haehling, Berlin Jorgen Hegbrant, Lund Alp Ikizler, Nashville, Tenn. Hideki Kawanishi, Hiroshima William F. Keane, Minneapolis, Minn. John A. Kellum, Pittsburgh, Pa. Peter Kotanko, New York, N.Y. Martin K. Kuhlmann, Berlin Nathan W. Levin, New York, N.Y. Francesco Locatelli, Lecco Peter McCullough, Novi, Mich. Madhukar Misra, Columbia, Mo. Allen R. Nissenson, Los Angeles, Calif. Mark Okusa, Charlottesville, Va. 


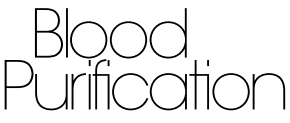

(Continued)

\section{Critical Care Nephrology}

Norbert Lameire, Ghent

Alan Maisel, San Diego, Calif.

Alexandre Mebazaa, Paris

Ravindra L. Mehta, San Diego, Calif.

Bruce Molitoris, Indianapolis, Ind.

Patrick T. Murray, Dublin

Federico Nalesso, Vicenza

Mark Okusa, Charlottesville, Va.

Heleen M. Oudemans-Van Straaten, Amsterdam

Paul M. Palevsky, Pittsburgh, Pa.

Didier Payen, Paris

Pasquale Piccinni, Vicenza

Piotr Ponikowski, Wroclaw

John R. Prowle, London

V. Marco Ranieri, Turin

Zaccaria Ricci, Rome

Marie Schetz, Leuven

Andrew Shaw, Durham, N.C.

Shigehiko Uchino, Tokio

David Warnock, Birmingham, Ala.

\section{Peritoneal Dialysis}

Miguel Perez Fontan, A Coruña

Beth M. Piraino, Pittsburgh, Pa.

Giuseppe Remuzzi, Bergamo

Miguel C. Riella, Curitiba

Bengt Rippe, Lund

Jean-Philippe Ryckelynk, Caen

Dirk G. Struijk, Amsterdam

Isaac Teitelbaum, Aurora, Colo.

Josep Teixido-Planas, Badalona

Wim Van Biesen, Ghent

Christian Verger, Pontoise

Enrico E. Verrina, Genoa

Janusz Witowski, Poznan

\section{Hemodialysis}

Vincenzo Panichi, Pisa

Mauro Pittiruti, Rome

Michael Rocco, Winston-Salem, N.C.

Mitchell Rosner, Charlottesville, Va.

Antonio Santoro, Bologna

Daniel Schneditz, Graz

Sergio Stefoni, Bologna

Peter Stenvinkel, Stockholm

Andrea Stopper, Bad Homburg

Ciro Tetta, Bad Homburg

Angela Y. Wang, Hong Kong

Richard Ward, Louisville, Ky.

Dick de Zeeuw, Groningen

Robert Zietse, Rotterdam

Carmine Zoccali, Reggio Calabria 


\section{Aims and Scope}

Practical information on hemodialysis, hemofiltration, peritoneal dialysis and plasma filtration is featured in this journal. Recognizing the critical importance of equipment and procedures, particular emphasis has been placed on reports, drawn from a wide range of fields, describing technical advances and improvements in methodology. Papers reflect the search for cost-effective solutions which increase not only patient survival but also comfort through prevention or correction of undesirable effects. Advances in vascular access and blood anticoagulation, problems associated with exposure of blood to foreign surfaces and acute-care nephrology, including continuous therapies, also receive attention. $\mathrm{Ne}$ phrologists, internists, intensivists and hospital staff involved in dialysis, apheresis and immunoadsorption for acute and chronic solid organ failure will find this journal useful and informative.

\section{Submission}

Manuscripts written in English are considered and should be submitted online at

\section{www.karger.com/bpu}

Should you experience problems with your submission, please contact

$$
\begin{aligned}
& \text { Editorial Office 'Blood Purification' } \\
& \text { S. Karger AG } \\
& \text { PO Box } \\
& \text { CH-4009 Basel (Switzerland) } \\
& \text { Tel. +41 } 613061356 \\
& \text { Fax +41 } 613061434 \\
& \text { E-Mail bpu@karger.com }
\end{aligned}
$$

\section{Conditions}

All manuscripts are subject to editorial review. Manuscripts are received with the explicit understanding that they are not under simultaneous consideration by any other publication. Submission of an article for publication implies transfer of the copyright from the author to the publisher upon acceptance. Accepted papers become the permanent property of Blood Purification and may not be reproduced by any means, in whole or in part, without the written consent of the publisher. It is the author's responsibility to obtain permission to reproduce illustrations, tables, etc. from other publications.

\section{Conflicts of Interest}

Authors are required to disclose any sponsorship or funding arrangements relating to their research and all authors should disclose any possible conflicts of interest. Conflict of interest statements will be published at the end of the article.

\section{Ethics}

Published research must comply with the guidelines for human studies and animal welfare regulations. Authors should state that subjects have given their informed consent and that the study protocol has been approved by the institute's committee on human research. Further, they should also state that animal experiments conform to institutional standards.

\section{Categories of Manuscripts}

(Word limits include tables, illustrations and references)

- Original Papers are full-length research papers which will be considered for the journal. Articles cover topics relevant to blood cleansing studies (max. 2,500 words).

- In-Depth Reviews are comprehensive, state-of-theart papers (systematic reviews or meta-analyses) on important clinical problems of hemodialysis, hemofiltration, peritoneal dialysis and plasma filtration. In-Depth Reviews may be invited by the Editor or they may be unsolicited ( $\max$. 5,000 words), although in the latter, we ask the author to send the Editor a short outline first (300-400 words) to ensure that a review on a similar subject has not already been commissioned. Manuscripts will be assessed in-house and those judged suitable will be peer-reviewed before an editorial decision is made.

- Editorials are usually invited by the Editor (max. 1,000 words). Please send suggestions to the Editor.

- Methods in Blood Purification papers dealing with methodological issues in blood purification studies (e.g. recruitment, exclusion and inclusion criteria, methodological evaluation, novel approaches to clinical trials, statistical analyses and follow-up problems and solutions), particularly with regard to on-going large population-based studies, controlled clinical trials, cohort and case-control studies are welcome (max. 5,000 words)

- Letters to the Editor and Opinions. Manuscripts of max. 500 words, 1 figure or table and max. 10 references are considered for publication provided they describe a novel observation or add pertinent new information.

\section{Arrangement}

Title page: The first page of each paper should indicate the title, the authors' names, the institute where the work was conducted, and a short title for use as running head.

Full address: The exact postal address of the corresponding author complete with postal code must be given at the bottom of the title page. Please also supply phone and fax numbers, as well as e-mail address.

Key words: Please supply 3-10 key words in English that reflect the content of the paper.

Abstract: Each paper needs an abstract in English of not more than 150 words. It should be structured as follows:

Background/Aims: What is the major problem that prompted the study? Results: Most important findings? Conclusion: Most important conclusion?

Abstract of In-Depth Reviews: Should be divided into the following subsections: Background, Summary and Key Messages. The Background should provide a brief clinical context for the review and is followed by the Summary, which should include a concise description of the main topics covered in the text. The Key Messages encapsulate the main conclusions of the review.
Footnotes: Avoid footnotes.

Tables and illustrations: Tables and illustrations (both numbered in Arabic numerals) should be prepared on separate pages. Tables require a heading and figures a legend, also prepared on a separate page. For the reproduction of illustrations, only good drawings and original photographs can be accepted; negatives or photocopies cannot be used. Due to technical reasons, figures with a screen background should not be submitted. When possible, group several illustrations in one block for reproduction (max. size $180 \times 223 \mathrm{~mm}$ ) or provide crop marks. Electronically submitted b/w half-tone and color illustrations must have a final resolution of 300 dpi after scaling, line drawings one of 800-1,200 dpi.

\section{Color illustrations}

Online edition: Color illustrations are reproduced free of charge. In the print version, the illustrations are reproduced in black and white. Please avoid referring to the colors in the text and figure legends.

Print edition: Up to 6 color illustrations per page can be integrated within the text at CHF 800.- per page.

References: In the text identify references by Arabic numerals [in square brackets]. Material submitted for publication but not yet accepted should be noted as [unpublished data] and not be included in the reference list. The list of references should include only those publications which are cited in the text. Do not alphabetize; number references in the order in which they are first mentioned in the text. The surnames of the authors followed by initials should be given. There should be no punctuation other than a comma to separate the authors. Preferably, please cite all authors. Abbreviate journal names according to the Index Medicus system. Also see International Committee of Medical Journal Editors: Uniform requirements for manuscripts submitted to biomedical journals (www.icmje.org).

Examples

(a) Papers published in periodicals: Samouilidou E, Grapsa E: Effect of dialysis on plasma total antioxidant capacity and lipid peroxidation products in patients with end-stage renal failure. Blood Purif 2003;21:209-212.

(b) Papers published only with DOI numbers:

Theoharides TC, Boucher W, Spear K: Serum interleukin-6 reflects disease severity and osteoporosis in mastocytosis patients. Int Arch Allergy Immunol DOI: $10.1159 / 000063858$.

(c) Monographs: Tomino Y: IgA Nephropathy. From Molecules to Men, ed 1. Basel, Karger, 1999.

(d) Edited books: Cochrane AL, Ricardo SD: Oxidant stress and regulation of chemokines in the development of renal interstitial fibrosis; in Razzaque MS, Taguchi T (eds): Renal Fibrosis. Contrib Nephrol. Basel, Karger, 2003, vol 139, pp 102-119.

Reference Management Software: Use of EndNote is recommended for easy management and formatting of citations and reference lists.

\section{Digital Object Identifier (DOI)}

S. Karger Publishers supports DOIs as unique identifiers for articles. A DOI number will be printed on the title page of each article. DOIs can be useful in the future for identifying and citing articles published

\section{KARGER}

E-Mail karger@karger.com www.karger.com
(C) 2014 S. Karger AG, Basel 
online without volume or issue information. More information can be found at www.doi.org.

\section{Supplementary Material}

Supplementary material is restricted to additional data that are not necessary for the scientific integrity and conclusions of the paper. Please note that all supplementary files will undergo editorial review and should be submitted together with the original manuscript. The Editors reserve the right to limit the scope and length of the supplementary material. Supplementary material must meet production quality standards for Web publication without the need for any modification or editing. In general, supplementary files should not exceed $10 \mathrm{Mb}$ in size. All figures and tables should have titles and legends and all files should be supplied separately and named clearly. Acceptable files and formats are: Word or PDF files, Excel spreadsheets (only if the data cannot be converted properly to a PDF file), and video files (.mov, .avi, .mpeg).

\section{Author's Choice ${ }^{\mathrm{TM}}$}

Karger's Author's Choice ${ }^{\mathrm{TM}}$ service broadens the reach of your article and gives all users worldwide free and full access for reading, downloading and printing at www.karger.com. The option is available for a onetime fee of CHF 3,000.-, which is a permissible cost in grant allocation. More information can be found at www.karger.com/authors_choice.

\section{NIH-Funded Research}

The U.S. National Institutes of Health (NIH) mandates under the NIH Public Access Policy that final, peer-reviewed manuscripts appear in its digital database within 12 months of the official publication date. As a service to authors, Karger submits the final version of your article on your behalf to PubMed Central. For those selecting our premium Author's Choice $^{\mathrm{TM}}$ service, we will send your article immediately upon publishing, accelerating the accessibility of your work without the usual embargo. More details on NIH's Public Access Policy is available at http:// publicaccess.nih.gov/FAQ.htm\#a1

\section{Self-Archiving}

Karger permits authors to archive their pre-prints (i.e. pre-refereeing) or post-prints (i.e. final draft post-refereeing) on their personal or institution's servers, provided the following conditions are met: Articles may not be used for commercial purposes, must be linked to the publisher's version, and must acknowledge the publisher's copyright. Authors selecting Karger's Author's Choice ${ }^{\mathrm{TM}}$ feature, however, are also permitted to archive the final, published version of their article, which includes copyediting and design improvements as well as citation links.

\section{Page Charges}

There are no page charges for papers of 2 printed pages. Each additional complete or partial page will be charged to the author at a rate of CHF 325.00 per page.

\section{Proofs}

Unless indicated otherwise, proofs are sent to the corresponding author and should be returned with the least possible delay. Alterations made in proofs, other than the correction of printer's errors, are charged to the author.

\section{Reprints}

Order forms and a price list are sent with the proofs. Orders submitted after the issue is printed are subject to considerably higher prices.

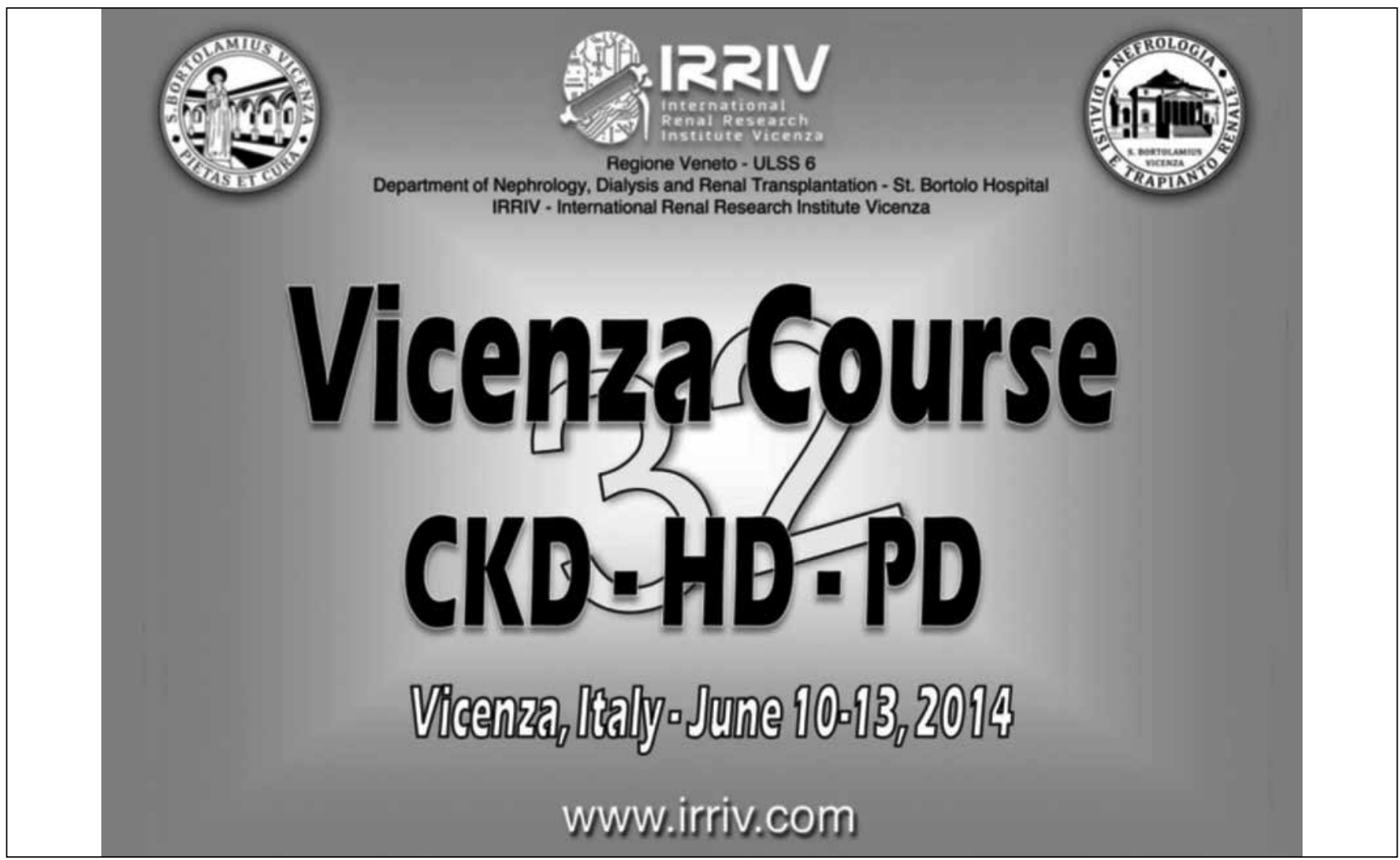

F14221

\section{KARGER}

E-Mail karger@karger.com www.karger.com
(C) 2014 S. Karger AG, Basel

The Journal Home Page is available at: www.karger.com/bpu 
ISSN Print Edition: 0253-5068 ISSN Online Edition: 1421-9735

Journal Homepage: www.karger.com/bpu

Publication Data: Blood Purification is published 8 times a year. Volumes 37 and 38 , each with 4 issues, appear in 2014

Copyright: (c) 2014 S. Karger AG, Basel (Switzerland). All rights reserved. No part of this publication may be translated into other languages, reproduced or utilized in any form or by any means, electronic or mechanical including photocopying, recording, microcopying, or by any information storage and retrieval system, without permission in writing from the publisher or, in the case of photocopying, direct payment of a specified fee to the Copyright Clearance Center.

Disclaimer: The statements, opinions and data contained in this publication are solely those of the individual authors and contributors and not of the publisher and the editor(s). The appearance of advertisements in the journal is not a warranty, endorsement, or approval of the products or services advertised or of their effectiveness, quality or safety. The publisher and the editor(s) disclaim responsibility for any injury to persons or property resulting from any ideas, methods, instructions or products referred to in the content or advertisements.
Subscription Rates: Subscriptions run for a full calendar year. Prices are given per year. Personal subscription:

Print or Online

CHF 961.-

EUR 787.-

USD 961.00

Print+Online combined

EUR 865.

USD 1031.00

postage and handling (added to print and print+online)

CHF 59.20 Europe, CHF 86.40 Overseas

EUR 48.-

USD 78.40

Institutional subscription:

Print+Online combined

CHF 3202.

EUR 2624.-

CHF 3522.-

USD 3202.00

USD 3522.00

postage and handling (added to print and print+online)

CHF 74.- Europe, CHF 108.- Overseas

EUR 60.-

USD 98.00

Discount subscription prices:

- International Society of Blood Purification(ISBP)

- Japan Society for Blood Purification in

Critical Care (JSBPCC)

- Japanese Society of Hemodiafiltration (JS-HDF)

- Chinese Society of Blood Purification

Administration (CSBPA)
Back Volumes and Single Issues: Information on availability and prices of single print issues and print or electronic back volumes can be obtained from Customer Service atservice@karger.com.

Bibliographic Indices: This journal is regularly listed in bibliographic services, including Current Contents ${ }^{\circledR}$ and PubMed/MEDLINE.

Photocopying: This journal has been registered with the Copyright Clearance Center (CCC), as indicated by the code appearing on the first page of each article. For readers in the US, this code signals consent for copying of articles for personal or internal use, or for the personal or internal use of specific clients, provided that the stated fee is paid per copy directly to

Copyright Clearance Center Inc.

222 Rosewood Drive

Danvers, MA 01923 (USA)

A copy of the first page of the article must accompany payment. Consent does not extend to copying for general distribution, for promotion, for creating new works, or for resale. In these cases, specific written permission must be obtained from the copyright owner,

S. Karger AG, P.O. Box

CH-4009 Basel (Switzerland).

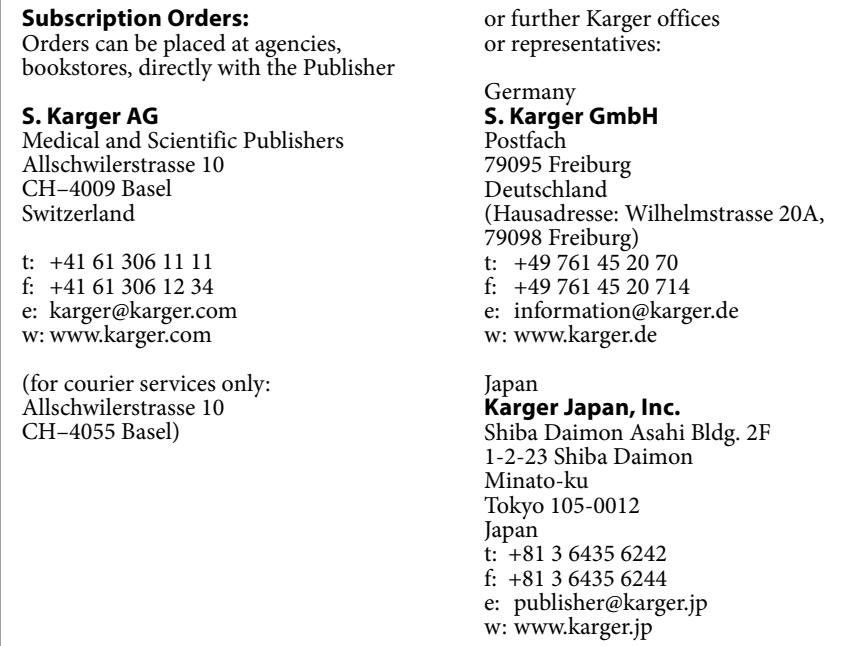

USA

S. Karger Publishers, Inc.

26 West Avon Road

P.O. Box 529

Unionville, CT 06085

USA

Toll free: +18008285479

t: +18606757834

t: $\quad+18606757834$

e: karger@snet.net

France

Enter \& Read

Albertine Luginbuh

23, rue du Départ, boite 37

75014 Paris

France

t: $+33(0) 681047685$

e: albertineluginbuhl@orange.fr

South East Asia, China and Taiwan

Karger Regional Office (Malaysia)

CEO Suite Kuala Lumpur

Quill 7, 27th Floor

Jalan Stesen Sentral 5

KL Sentral

Kuala Lumpur 50470

Malaysia

t: +60327766803

f: +60327766999

e: service@karger.cn

\section{Karger China}

West/5F, China Life Towe

No.16, Chao Wai Street

Chaoyang District

Beijing 100020

China

t. +861058771408

f: +861058771120

e: service@karger.cn; r.chew@karger.cn

w: www.karger.cn

India, Bangladesh, Sri Lanka

Karger India

Plot No. 17, Yusuf Sarai Market

B.L. Glass Building, 2nd Floor

Sri Aurobindo Marg

New Delhi 110016

India

t: +911146029633

f: +911146029634

c: +919891052 128

e: r.kumar@kargerindia.com

w: www.karger.com

Change of Address:

Both old and new address should be sent

to the subscription source.

\section{KARGER}

E-Mail karger@karger.com www.karger.com
(C) 2014 S. Karger AG, Basel

The Guidelines for Authors are available at: www.karger.com/bpu_Guidelines 


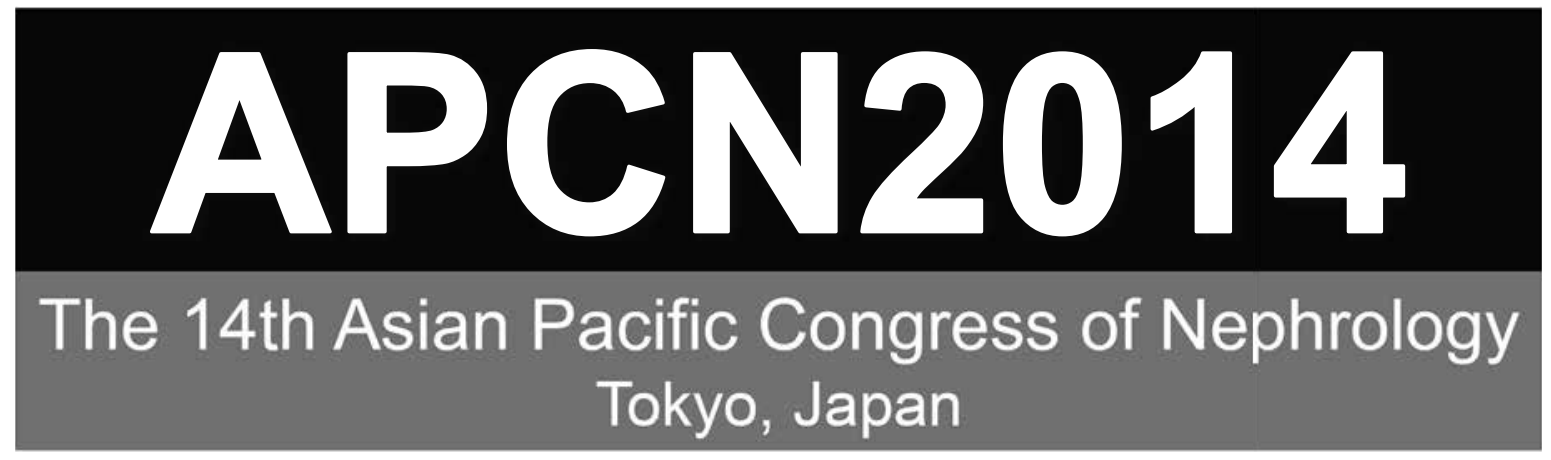

\begin{tabular}{|c|c|c|}
\hline $\begin{array}{r}\text { Date : May } \\
\text { Venue : S } \\
\text { Congress Preside } \\
\text { (Professor, Division of } \\
\text { Juntendo Univers }\end{array}$ & $\begin{array}{l}\text { Wed) - } 17 \text { (Se } \\
\text { Igawa Prince } \\
\text { Yasuhiko To } \\
\text { logy, Department of } \\
\text { culty of Medicine, To }\end{array}$ & $\begin{array}{l}14 \\
\text { MD, PhD } \\
\text { Medicine, } \\
\text { an) }\end{array}$ \\
\hline Registration fee & $\begin{array}{c}\text { Early } \\
\text { (by Feb 28, 2014) }\end{array}$ & $\begin{array}{l}\text { Late } \\
\text { (after Mar 1, 2014) }\end{array}$ \\
\hline Doctors / Others & JPY 35,000 & JPY 45,000 \\
\hline $\begin{array}{l}\text { Student / Fellow / Trainee / Nurse / } \\
\text { Allied Health Care Staff }\end{array}$ & \multicolumn{2}{|c|}{ Free } \\
\hline Accompanying Person(s) & JPY 10,000 & JPY 10,000 \\
\hline
\end{tabular}

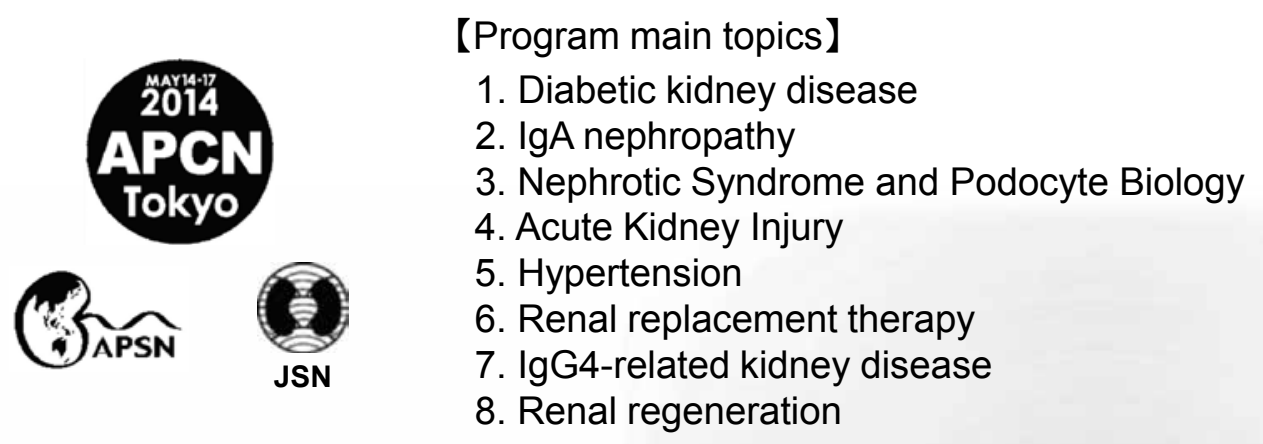

\section{《Period of Abstract Submission 》 \\ September 10 (Tue) - December 10 (Tue), 2013 \\ *Date and time should follow the Japanese Standard Time}

Further conference information should be checked on the website!

\section{URL: http://www.mtoyou.jp/apen2014/ I}

\section{E-mail: apcn2014@mtoyou.jp}


$15^{\text {th }}$ Congress of the International

Society of Peritoneal Dialysis
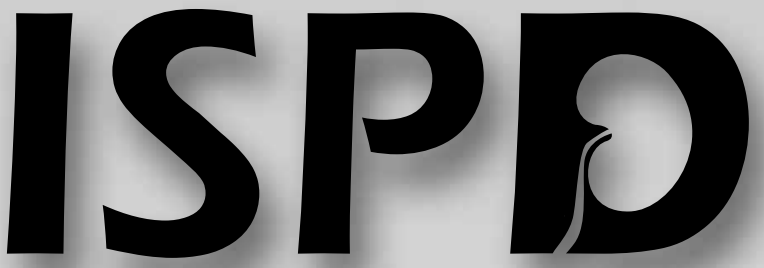

7th - 10th September, 2014
Madrid, Spain

7th - 10th September, 2014
Madrid, Spain

www.ispdmadrid20 14.com
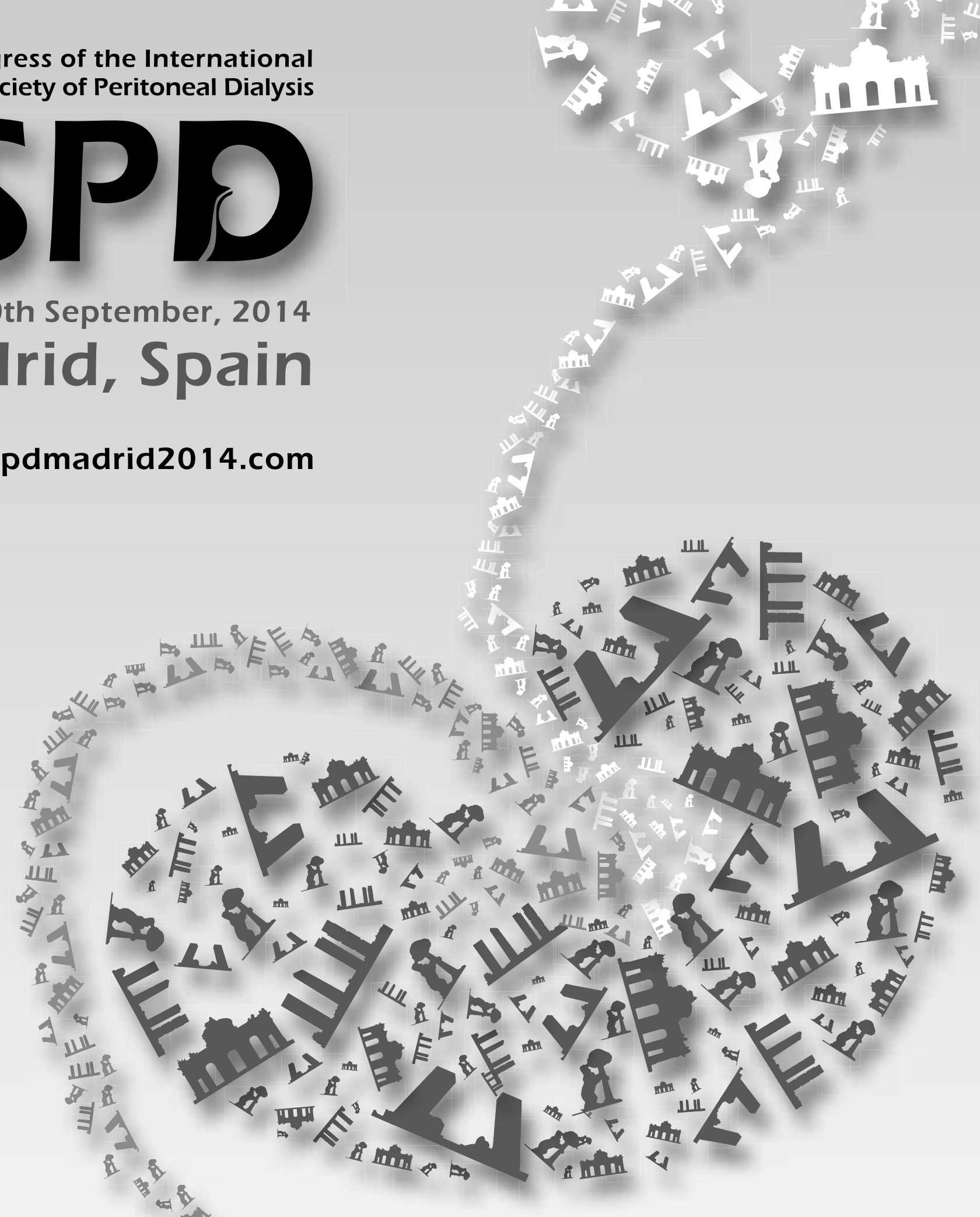

Important Deadlines 年

Abstract Submission

March 14 ${ }^{\text {th }} 2014$

Early Bird Registration July $15^{\text {th }} 2014$

\section{PD: The Patient Comes First !}

\section{8 if}

\section{III}




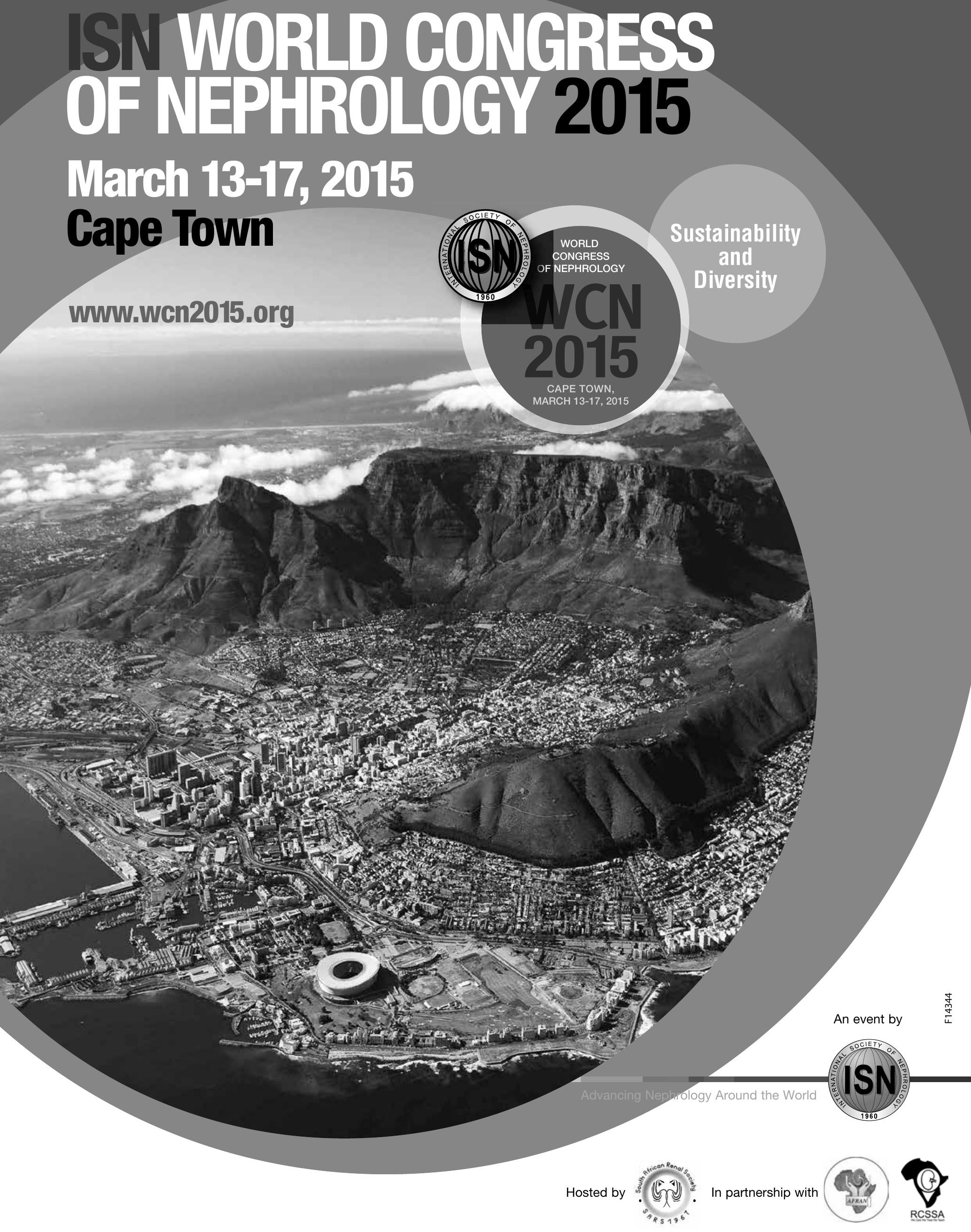




\section{Contents}

See the journal website for contents

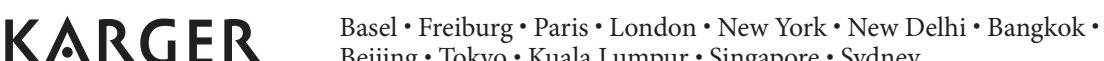
Beijing $\cdot$ Tokyo $\cdot$ Kuala Lumpur $\cdot$ Singapore $\cdot$ Sydney 

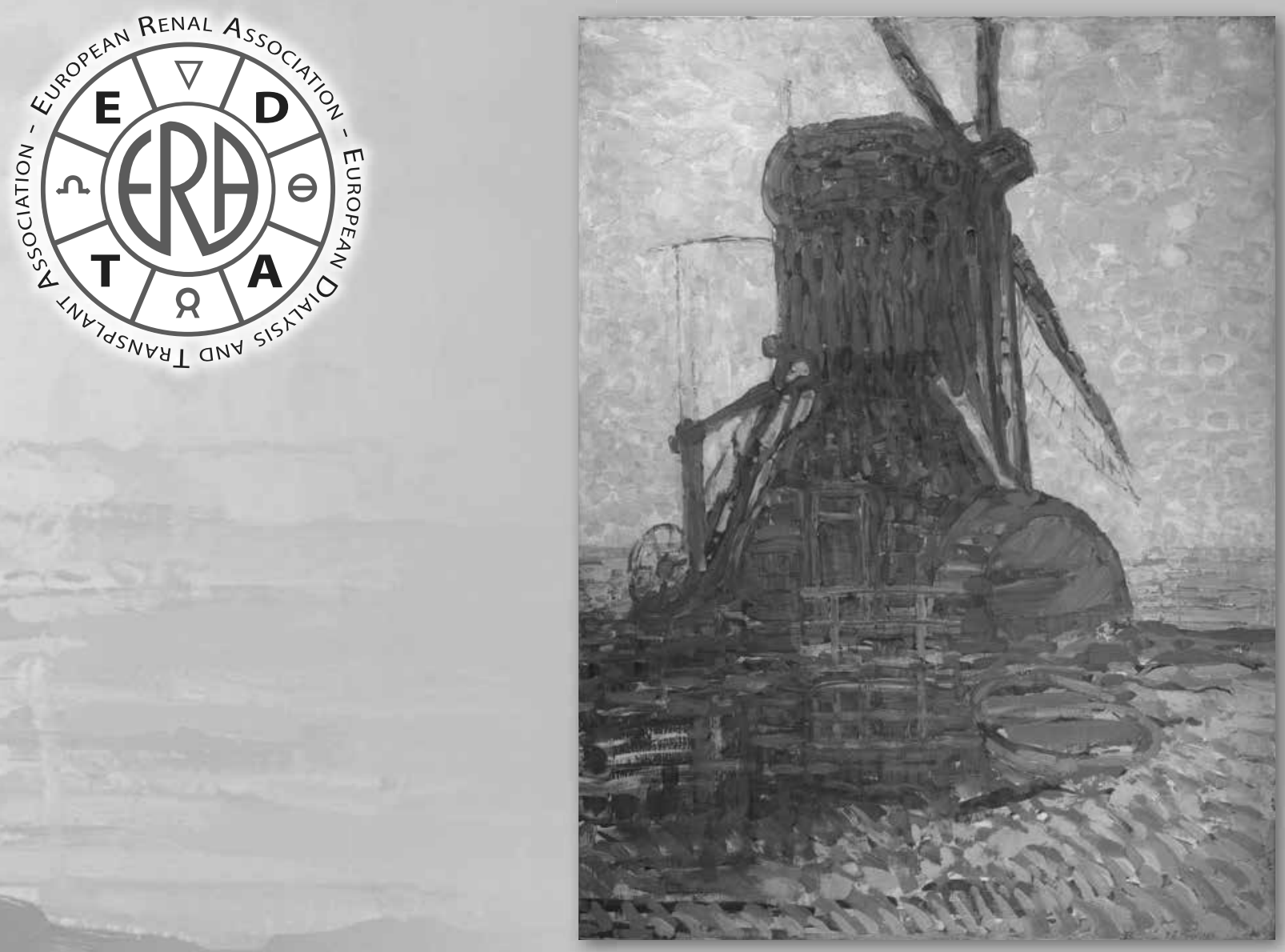

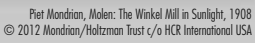
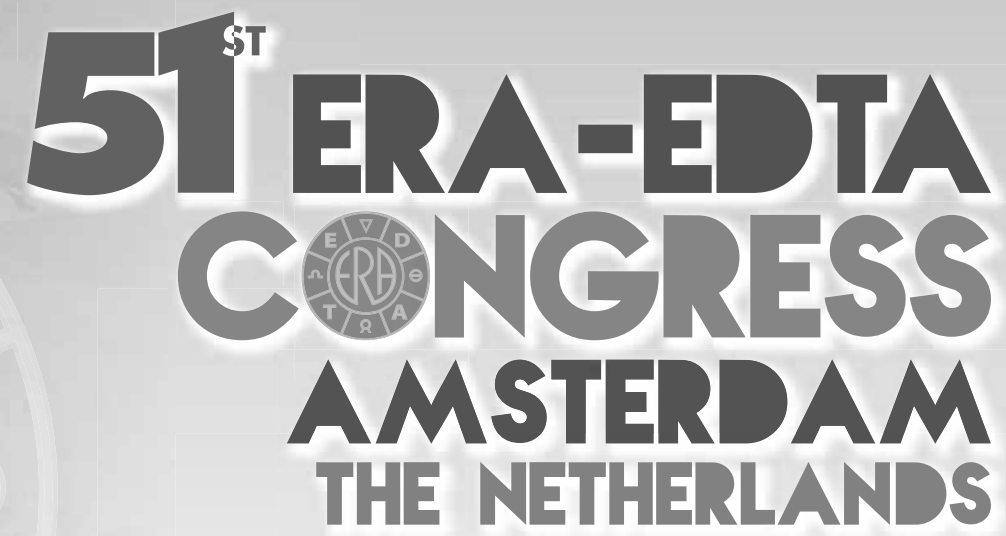
MAY 3' JUNE 3

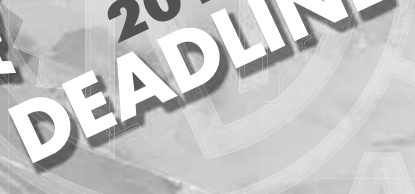

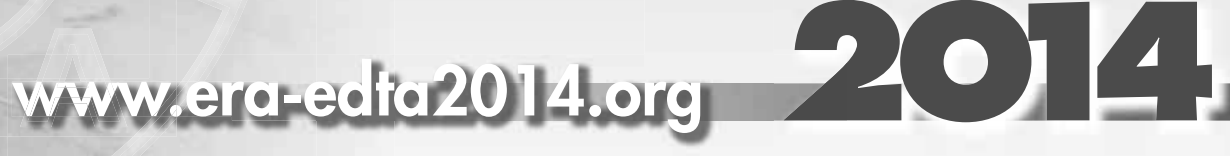




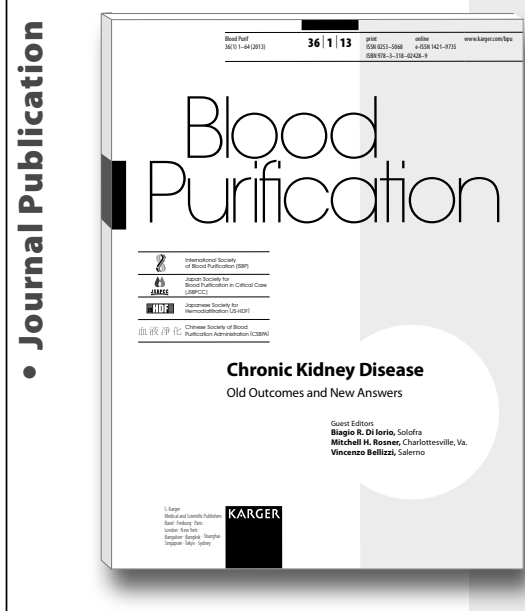

\title{
Chronic Kidney Disease
} Old Outcomes and New Answers

\author{
Editors \\ B.R. Di lorio \\ M.H. Rosner \\ V. Bellizzi
}

Chronic Kidney Disease

Old Outcomes and New Answers

Editors: Di lorio, B.R. (Solofra); Rosner, M.H.

(Charlottesville, Va.); Bellizzi, V. (Salerno)

64 p., 10 fig., 10 tab., 2013

CHF 29.- / EUR 24.- / USD 34.00 (soft cover)

CHF 35.- / EUR 29.- / USD 41.00 (online)

Online version for institutional purchase

Prices subject to change

EUR price for Germany, USD price for USA only

ISBN 978-3-318-02428-9 (soft cover)

e-ISBN 978-3-318-02429-6

Special Topic Issue:

Blood Purification

Vol. 36, No. 1 (2013)

Included in subscription

Listed in MEDLINE/PubMed

Dear Librarian

I have reviewed this publication and

would like to recommend it for our library.

Recommended by:

Department:

Date:

Signature:

Orders may be placed with any bookshop,

subscription agency, directly with the publisher

or through a Karger distributor.

\section{Contents}

\section{Editorial}

- Chronic Kidney Disease: Old Outcomes and New Answers: Rosner, M.H.

- Genomics and Proteomics: How Long Do We Need to Reach

Clinical Results? Matafora, V.; Bachi, A.; Capasso, G.

- Paricalcitol and Cardiorenal Outcome: From the IMPACT Study

to Clinical Practice: Bellasi, A.; Galassi, A.; Salvi, P.; Cozzolino, M.

- Coronary Artery Calcification and Outcomes in

Diabetic Patients with and without Chronic Kidney Disease:

Russo, D.; Morrone, L.F.P.; Imbriaco, M.; Pota, A.; Russo, L.;

Scognamiglio, B.; Sorrentino, R.

- Does It Make Sense to Measure Only the Brachial Blood

Pressure? Salvi, P.; Bellasi, A.; Di lorio, B.

- Subendocardial Viability Ratio Predicts Cardiovascular Mortality in Chronic Kidney Disease Patients: Di Micco, L.; Salvi, P.; Bellasi, A.; Sirico, M.L.; Di lorio, B.

- Higher Doses of Erythropoietin-Stimulating Agents and Hyporesponsiveness to Their Effects Are Associated with Increased Mortality among Prevalent Hemodialysis Patients: Nishio, A.; Chhatkuli, B.P.; Ma, J.Z.; Kalantari, K.

- Therapy of Anemia: Is It Only a Number to Reach or Are There Other Variables to Control? Del Vecchio, L.; Locatelli, F.

- Low-Protein Diet or Nutritional Therapy in Chronic Kidney

Disease? Bellizzi, v.

- Personal Daily Dialysis: The Evolution of the Artificial Kidney: Kim, J.C.; Ronco, C.

- FGF23: A Mature Renal and Cardiovascular Risk Factor? Zoccali, C.; Yilmaz, M.l.; Mallamaci, F.

- Blood Pressure Variability in Chronic Kidney Disease Patients: Mallamaci, F.; Tripepi, G. 


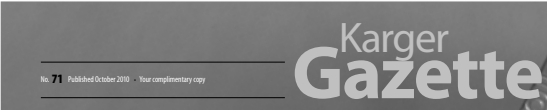

At the Cutting Edge

Swiss

Pioneers

in

Science /

and

Medicine

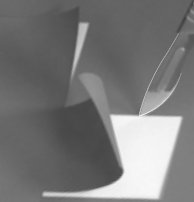

\section{Gazertte}

Stimulating reading in and around the world of medicine

The biomedical themes of the Karger Gazette are topical, urgent, exciting. Its articles, written by experts from all over the world, provide a wide audience with the basic issues, new findings and controversies in a lively and readable style. Alongside invited contributions, each number carries attractively presented support material, such as informative graphics, historical summaries, interviews, or portraits of individuals and institutions. The Karger Gazette is published in newspaper format and appears once a year.

And what's more - it's free!

To see behind the cover, please write or e-mail us, and we'll start your subscription with the latest issue. www.karger.com/gazette

Current issue:

\section{Anatomy and Art through the Ages}

with articles on

- Andreas Vesalius, his times and his ground-breaking atlas 'De humani corporis fabrica'

- Why history of medicine matters

- Art and the science of appearance

- Medical art and illustration

\section{KARGER $\begin{gathered}\text { s. Karger AG } \\ \text { Karger Gazette }\end{gathered}$}

Allschwilerstrasse 10

CH-4009 Basel (Switzerland)

E-Mail gazette@karger.com

www.karger.com 


\title{
An essential manual for beginners and senior researchers alike
}

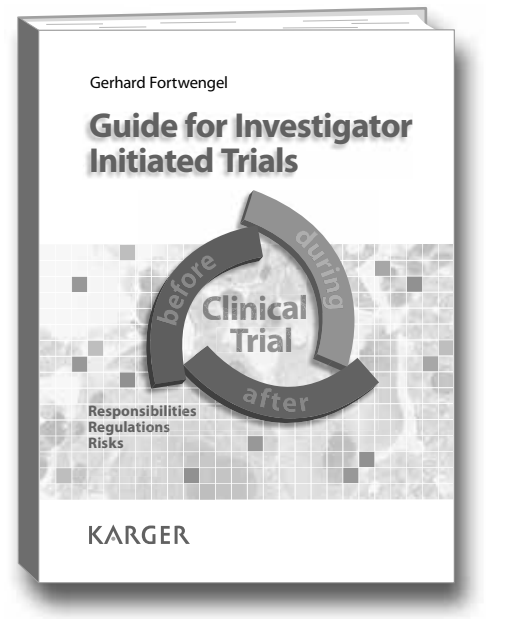

\section{Guide for Investigator Initiated Trials}

\author{
Editor \\ Gerhard Fortwengel
}

In collaboration with:

Isabel Böckler, Rafael Dymek, Sebastian Häckl, Alexander Hahn, Katrin Hertwig, Cynthia Kuhn, Birgit Lindner, Sarah Lütkens, Christoph Neumann, Marcus Paul, Madlen Pomp, Nadja Schachteli

For academic medical faculty unfamiliar with national and international regulations, the prospect of initiating and managing a clinical trial can be intimidating. The development of protocols and case report forms, compliance with regulatory requirements, the monitoring of clinical trials as well as the responsibilities of documentation are just some of the tasks the sponsor-investigator is faced with.

This book covers the entire spectrum of a clinical trial, reviewing the different stages step by step: financial planning, crucial aspects of trial design, the authorization process and, finally, documentation. Moreover, it contains helpful tips, a practical glossary, instructions and a large number of resources related to the relevant regulations and forms conforming to the 'International Conference on Harmonization and Good Clinical Practice' and the European legislation. This makes the publication at hand an essential 'cookbook' for both academic faculty new to clinical trials as well as seasoned sponsors-investigators.

\section{Contents}

- Risk-Benefit Analysis

- Study Types and Study Design

- Investigational Medicinal Products

- Study Protocol

- Case Report Forms

- Financing

- Qualifications, CVs of Site Staff, Training, Delegation of Authority

- EudraCT

- Contracts

- Informed Consent

- Investigator's Brochure/Summary of Product Characteristics

- Insurance

- Health Authority Approval

- Ethics
- Trial Master File, Updating and Archiving

- Documentation

- Data Management

- Screening

- Pharmacovigilance

- Patient Compliance

- Source Data Verification

- Quality

- Monitoring

- Biometry

- Multicentre Trials

- Final Study Report and Publication

- Appendix 1: Common Abbreviations

- Appendix 2: Glossary

- Appendix 3: Health Authority Addresses in the European Area

www.karger.com/documentation

Guide for Investigator Initiated Trials Editor: Fortwengel, G. (Hannover)

$\mathrm{VI}+148$ p., 7 fig., spiral bound, 2011 CHF 49.- / EUR 41.- / USD 58.00 Prices subject to change

EUR price for Germany, USD price for USA only

ISBN 978-3-8055-9684-8

e-ISBN 978-3-8055-9685-5

\section{Please send: _ copy/ies}

Postage and handling free with prepayment

E

Payment:

Please charge to my credit card

- $\square$ American Express $\square$ Diners $\square$ Eurocard

ᄂ $\square$ MasterCard $\square$ Visa

- Card No.

$\boldsymbol{\top}$

ర Exp. date:

- CVV/CVC

( 3 digits in the signature field on the back of Visa and MasterCard)

$\square$ Check enclosed $\square$ Please bill me

Orders may be placed with any bookshop, subscription agency, directly with the publisher or through a Karger distributor.
Fax: +41 613061234

S. Karger AG, P.O. Box, CH-4009 Basel (Switzerland) E-Mail orders@karger.ch,www.karger.com

Name/Address: 


\section{The expert source of research and practice for nephrologists, cardiologists and critical care physicians}

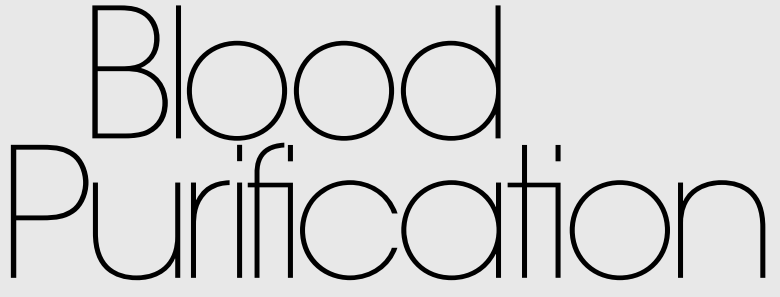

Editor-in-Chief

C. Ronco, Vicenza

Assistant Editor

S. Chiaramonte, Vicenza
Official Journal of the

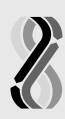

International Society of

Blood Purification (ISBP)

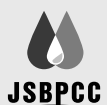

Japan Society for Blood Purification in Critical Care (JSBPCC)

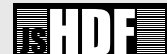

Japanese Society of Hemodiafiltration (JS-HDF)

血液淨化

Chinese Society of

Blood Purification Administration (CSBPA)

\section{More information at}

\section{www.karger.com/bpu}

- Pay-per-View and Subscriber Access to Full Text

- Full Table of Contents

- Full Editorial Board

- Free Abstracts and Selected Articles

- Online Sample Issue

- Submission/Guidelines for Authors

- Subscription Details

- Free Alert Service

- Online Library Recommendation

lood Purification

2014: Volumes 37, 38

4 issues per volume

Language: English

ISSN 0253-5068 (print)

ISSN 1421-9735 (online)

\section{Selected contributions}

- Vascular Calcifications, Arterial Aging and Arterial Remodeling in ESRD:

London, G.M.; Pannier, B.; Marchais, S.J. (Fleury-Mérogis)

- Reasons for the Lack of Salutary Effects of Cholesterol-Lowering Interventions in End-Stage Renal Disease Populations: Vaziri, N.D. (Irvine, Calif.);

Norris, K.C. (Los Angeles, Calif.)

- Emerging Clinical Evidence on Online Hemodiafiltration: Does Volume of

Ultrafiltration Matter?: Canaud, B. (Bad Homburg/Montpellier); Bowry, S.K. (Bad Homburg)

- New Diagnostic Tests and New Therapies for Glomerular Diseases: Appel, G.B.;

Appel, A.S. (New York, N.Y.)

- Hydrodynamic Analysis of the Miniaturized Hemofilter for a Wearable

Ultrafiltration Device: Ronco, C. (Vicenza); Kim, J.C. (Vicenza/Seoul); Garzotto, F. (Vicenza); Galavotti, D.; Bellini, C.; Brolgli, M. (Medolla); Nalesso, F. (Vicenza)

- Advanced Glycation End Products and $\beta_{2}$-Microglobulin as Predictors of Carpal Tunnel Syndrome in Hemodialysis Patients: Busch, M.; Schwenzky, A.; Franke, S.; Stein, G.; Wolf, G. (Jena)

- Cell-Based Strategies for the Treatment of Kidney Dysfunction: A Review: Pino, C.J. (Ann Arbor, Mich.); Yevzlin, A.S. (Madison, Wisc.); Tumlin, J. (Chattanooga, Tenn.); Humes, H.D. (Ann Arbor, Mich.)

- Safe Use of Citric Acid-Based Dialysate and Heparin Removal in Postdilution Online Hemodiafiltration: Aniort, J.; Petitclerc, T.; Créput, C. (Paris)
Practical information on hemodialysis, hemofiltration, peritoneal dialysis and apheresis is featured in this journal. Recognizing the critical importance of equipment and procedures, particular emphasis has been placed on reports, drawn from a wide range of fields, describing technical advances and improvements in methodology. Papers reflect the search for cost-effective solutions which increase not only patient survival but also patient comfort and disease improvement through prevention or correction of undesirable effects. Advances in vascular access and blood anticoagulation, problems associated with exposure of blood to foreign surfaces and acute-care nephrology, including continuous therapies, also receive attention Nephrologists, internists, intensivists and hospital staff involved in dialysis, apheresis and immunoadsorption for acute and chronic solid organ failure will find this journal useful and informative. Blood Purification also serves as a platform for multidisciplinary experiences involving nephrologists, cardiologists and critical care physicians in order to expand the level of interaction between different disciplines and specialities. 


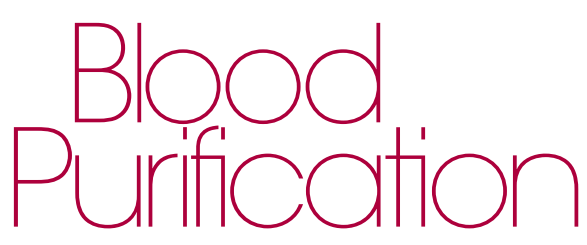

Obituary

73 In Memoriam: Stanley Shaldon, MD, FRCP, 1931-2013 Kaplan, A.A. (Farmington, Conn.); Davenport, A. (London); Zietse, R. (Rotterdam); Tesar, V. (Prague)

Editorial

1 Mixed Matrix Membranes: A New Asset for Blood Purification Therapies

Tijink, M.S.L. (Enschede); Kooman, J. (Maastricht); Wester, M. (Utrecht); Sun, J. (Enschede/Shanghai); Saiful, S. (Enschede); Joles, J.A. (Utrecht); Borneman, Z.; Wessling, M.; Stamatialis, D.F. (Enschede)

In-Depth Reviews

4 Prooxidative-Antioxidative Balance of Cells in Different Types of Renal Replacement Therapy

Stępniewska, J.; Dołęgowska, B.; Popińska, M.; Sałata, D.; Budkowska, M.; Gołembiewska, E.; Myślak, M.; Domański, M.; Marchelek-Myśliwiec, M.; Ciechanowski, K. (Szczecin)

57 Implantable Left Ventricular Assist Devices and the Kidney

Mao, H. (Vicenza/ Nanjing); Katz, N. (Baltimore, Md.); Kim, J.C.; Day, S.; Ronco, C. (Vicenza)

\section{Original Papers}

12 The Very Old on Hemodialysis: 8 Years' Experience in a Single Unit

Zingerman, B.; Korzets, A.; Ori, Y.; Herman-Edelstein, M.; Rozen-Zvi, B.; Gafter, U.; Chagnac, A. (Petach Tikva/Tel Aviv)

18 Hemodiafiltration Does Not Have Additional Benefits over Hemodialysis on Arterial Stiffness, Wave Reflections and Central Aortic Pressures Georgianos, P.I. (Thessaloniki/Serres); Sarafidis, P.A.; Karpetas, A.; Kosmidis, D.; Sioulis, A.; Liakopoulos, V. (Thessaloniki); Stamatiadis, D.N. (Serres); Papagianni, A.; Zebekakis, P.E.; Nikolaidis, P.; Lasaridis, A.N. (Thessaloniki)
27 Association between Endotoxin Activity and Acute Kidney Injury in Cardiac Patients Undergoing Cardiopulmonary Bypass

Paternoster, G. (Potenza); Rubino, G. (Bari); Balducci, A. (Pero); Maiorano, R.; Brienza, N. (Bari)

33 Low Hip Bone Mineral Density Predicts Mortality in Maintenance Hemodialysis Patients: A Five-Year Follow-Up Study

Disthabanchong, S.; Jongjirasiri, S.; Adirekkiat, S.; Sumethkul, V.; Ingsathit, A.; Domrongkitchaiporn, S.; Phakdeekitcharoen, B.; Kantachuvesiri, S.; Kitiyakara, C. (Bangkok)

39 Combined Extracorporeal Therapy for Severe Sepsis in Patients after Cardiac Surgery

Yaroustovsky, M.; Abramyan, M.; Krotenko, N.; Popov, D.; Plyushch, M.; Rogalskaya, E.; Nazarova, H. (Moscow)

48 Comparison of Bioimpedance Techniques to Detect Changes in Fluid Status in Hemodialysis Patients Abbas, S.R. (New York, N.Y.); Liu, L. (New York, N.Y./Beijing); Sipahioglu, M.H. (New York, N.Y./Kayseri); Rosales, L.; Carter, M.; Kotanko, P.; Levin, N.W.; Zhu, F. (New York, N.Y.)

67 Observational Study of Surveillance Based on the Combination of Online Dialysance and Thermodilution Methods in Hemodialysis Patients with Arteriovenous Fistulas

Fontseré, N.; Mestres, G.; Burrel, M.; Barrufet, M.; Montaña, X.; Arias, M.; Ojeda, R.; Maduell, F.; Campistol, J.M. (Barcelona)

76 Effects of AST-120 on Blood Concentrations of ProteinBound Uremic Toxins and Biomarkers of Cardiovascular Risk in Chronic Dialysis Patients

Lee, C.-T.; Hsu, C.-Y.; Tain, Y.-L.; Ng, H.-Y.; Cheng, B.-C.; Yang, C.-C.; Wu, C.-H.; Chiou, T.T.-Y.; Lee, Y.-T.; Liao, S.-C. (Kaohsiung)

Letter to the Editor / Reply

47 Comment on the Paper: Hospitalization and Mortality in Hemodialysis Patients: Association with Hemoglobin Variability Imamovic, G. (Tuzla) 